\title{
Pantheism in Wordsworth: A Study from the Islamic Perspective
}

\author{
MUHAMMAD AZIZUL HOQUE ${ }^{1}$
}

\begin{abstract}
William Wordsworth, a literary icon in romantic poetry, has impressed us with his pantheism and therefore, encouraged us to think of doing research into the concept with some modifications from Islamic perspective. It is, indeed, difficult to analyse the idea from Islamic perspective, because holding multidimensional concepts of God, and contradictory theories and hypotheses by some Muslim pundits and Sufis basing the concepts of other religions and ideas of God instead of authentic sources from the Holy Quran and Hadith, have made the general Muslims confused. Moreover, ideas like these may lead the believers to the Shirk (partnership) with God. So we have attempted to analyse the concept of the romantic poet along with the related concepts of some Sufis in the light of Islam with the support of some Qur'anic verses.
\end{abstract}

Keywords: Islam, pantheism, Wordsworth, Sufism

Wordsworth's pantheism is a faith-based idea supportive for those who want to develop Islamic criticism of English literature on the basis of Islamic tenets. Though the idea of Pantheism is implicitly contrary to oneness of God, it may encourage the researchers whose ultimate purpose is to know God through the study of disciplined natural objects of the universe available in English literature. Therefore, we have been impressed with Wordsworth's presentation and appreciation of nature. But discovering his idea of partial presence of God as some spirit in every natural element contrary to Islamic monotheism, we have tried to reshape the idea from the perspective of Islam basing the Quranic literature. The following verses of the holy Qur'an teach us how to think of Nature:

Do they not look at the camels, how they are made? And at the sky, how it is raised high? And at the mountains, how they are fixed firm? And at the earth, how it is spread out? Therefore do thou give admonition, for thou art one to admonish (88:17-20).

Even though there have been many works that have tried to analyze the concept of pantheism, especially that of Wordsworth, in comparison with Sufism, the concept is still unexplored from Islamic perspective. But the study of Ramli (2011) has explored the philosophy of Iqbal which can be supported by Islamic tenets. His comparative analysis between the philosophies of Romantics, especially of Wordsworth and Iqbal, has tried to show that unlike the Romantics, whose adherents' imagination led them to believe that God himself is embedded in Nature and truth or Reality is only its beauty, Iqbal shapes Nature's majestic presence from its ideal state into a medium for his intense yearning and longing for a sight of Allah (s.w.t.), a desire for a divinely-inspired intuition and the resulting intense love for this Creator. Like Romantics Iqbal's early poems, he adds, departs from a similar attention to Nature even though he does not go to the extent of worshipping it. He also observes while Iqbal exults

\footnotetext{
1 Muhammad Azizul Hoque, M.A., Assistant Professor at Dept. of English Language and Literature, International Islamic University Chittagong, CHITTAGONG 4203, Bangladesh, email: mazizhoque@yahoo.com.
} 
the beauty of nature and integrates them into his scheme of thought, Nature does not hold the answer to many of Iqbal's enquiries. Lines from Solitude read:

\author{
I left the moon and the sun behind, \\ And reached the presence of God. \\ I said, "Not one atom in Your world \\ Is intimate with me. \\ The world has no heart, \\ But I, though a handful of dust, am all heart. \\ It is a pleasant garden but unworthy of my song!" \\ A smile appeared on His lips - \\ He did not say a word.
}

In later poems, this intense sadness will result in longings for God, taking in the forms of various metaphors that constantly engage the poet's imagination but all seek to serve one thing, momentary intuitive closeness and knowledge of Allah (s.w.t.) (pp. 5-6). The above Quranic verses (88:17-20) echo this philosophy. He also observes, unlike Sufis, the intuitive knowledge of God's presence that Iqbal expresses in his poems is clearly devoid of its mystical dimensions by the poet's insistence that he remains separate from his Creator. It is from this separation that love emanates the poet's heart for his Allah (s.w.t.). Love then becomes the ultimate culmination of Iqbal's search for the knowledge of Reality in general and Allah (s.w.t.) in particular. In one of his poems, Iqbal even rejects the use of reason if it impedes one's experience of intuition and the resulting love for Allah (s.w.t.).

\author{
The custom of Love is abandonment of all \\ Abandon temple, mosque, and church also \\ This is not business, this is, ibadat of God! \\ 0 ignorant one, abandon the longing for \\ reward also \\ It is good to guard Intuition with Intellect \\ But sometimes you should let it go alone also \\ What life is that which is dependent on \\ others? (From "Ghazal" in The Caravan's Bell)
}

In summary, even though Romanticism was an eighteenth-century movement, Iqbal evidently saw in it some redeeming values such as a deep appreciation for imagination and Nature. However, unlike the Romantics, he chose not succumb to the idea of pantheism and extreme idealization of imagination. Instead, he saw in imagination the significance of intuition in creating an intense love for Allah (s.w.t.) in the internal self of man (pp. 7-8). Contrastingly, Golkhosravi (2001: 6) have studied the philosophy of Whitman and Rumi who have often claimed that nature, humankind and also the whole universe are images or attributes of God; signs of God the Divine Unity. They see humanity and nature as diverse images of one unifying force. Rumi describes such a unifying universal force as an archetypal force (like Shelley's 'wild spirit') and Whitman as an 'eidolon' and 'the seed perfection' (1982: 160). Such a cosmic and universal force has different terms in different creeds and schools, in Hinduism Brahman, in Sufism al-Haq and in Transcendentalism (for Whitman and Emerson) Santa Spirita or Over-soul. But Al-Attas (1995) realizes the nature of God understood in Islam is not the same as the conceptions of God understood in the various religious traditions of the world; nor is it the same as the conceptions of God understood in Greek and Hellenistic philosophical tradition; nor as the conceptions of God understood in Western philosophical or scientific tradition; nor in that of Occidental and Oriental mystical traditions. The apparent similarities that may be found between their various conceptions of God with the nature of God understood in Islam cannot be interpreted as evidence of identity of the One Universal God in their various conceptions of the 
nature of God; for each and every one of them serves and belongs to a different conceptual system, which necessarily renders the conception as a whole or the super system to be dissimilar with one another (p. 7). Again Rumi (as cited in Golkhosravi 2001: 6) realizes: "All this multiformity is one; whoever sees double is a squint-eyed mankind".

In Whitman's (1990: 419) A Persian Lesson, 'the greybeard Sufi' gives his 'last lesson' to 'the young priests and students'. He teaches God is everything, 'Allah is all, all, all', and Allah is 'immanent' in every object, animate and inanimate:

\section{Finally my children, to envelop each word, each part of the rest, Allah is all, all, all-is immanent in every life and object, May-be at many and many-a-more removes-yet Allah, Allah, Allah is there. It is the central urge in every atom ... (Golkhosravi 2001: 6-7).}

So here, we have come to know that the Muslim mystic poet and Sufi like Rumi too amalgamated his idea of God with other religious and philosophical views. Correspondingly, Abulafia's observation (cited in Wiseman 1990: 230) illustrates that anyone who has truly felt the divine touch and perceived its nature is no longer separated from his Master, and behold he is his Master and his Master is he; for he is so intimately adhering to Him that he cannot by any means be separated from Him, for he is He'.

\section{What is Pantheism?}

Before going to discuss on Wordswoth's pantheism, we should be introduced with the definition and historical background of pantheism. As we know pantheism is a doctrine of religious philosophy widely used by a group of poets and literary figures who think that God is everywhere in natural. Pantheism is the view that the Universe (Nature) and God are identical. Pantheists thus do not believe in a personal, anthropomorphic or creator god. The word derives from the Ancient Greek: pan meaning 'all' and theos meaning 'God'. As such, pantheism denotes the idea that 'God' is best seen as a process of relating to the Universe. Although there are divergences within pantheism, the central ideas found in almost all versions are the Cosmos as an all-encompassing unity and the sacredness of Nature (Mander 2012). From the classical to modern periods, it has been used in powerful literature by many literary scholars. Eagle (1970) defines it as 'the doctrine that God and the universe are identical' and so according to him 'God is everything, and everything is God' (implying a denial of the personality and transcendence of God) (p. 435). The concept began to spread more widely in the later 18th and early 19th centuries, in Germany with Goethe and Hegel, and in Britain with the romantic poets Wordsworth, Keats, and Shelley, and the transcendentalists in the USA - above all Emerson and Thoreau. During the 19th century it became the dominant literary art in glorifying nature. The concept of pantheism appears in different languages and expressions by scholars and poets of different ages and phases. Some of them are summed up below.

Virgil (70-19BC) visualizes 'Heaven and earth, the watered plains, the moon's shining globe, the sun and stars are all strengthened by some Spirit working within them [Aeneid vi. 724-727 (30-19BC)]. Likewise, William Wordsworth (1770-1850) thinks 'a motion and a spirit drive all thinking things, all objects of all thought, and rolls through all things' [Tintern Abbey, 102-104 (1798)]. John Keats (1795-1821) also maintains 'God does make individual beings, Souls, Identical Souls of the sparks of his own essence'. Leconte de Lisle (1818-1894) thinks the soul has different forms like bird, flower, living water, light and dives into the joyful beauty of this graceful world, and takes on our robe, primal purity, and rests, silently, in God [Le Bernica (1862)]. Similarly, Alfred Tennyson (1809-1892) assumes 'the sun, the moon, the stars, the seas, the hills and the plains' are all 'the Vision of Him who reigns' [The Higher Pantheism]. William Blake (1757-1827) maintains 'God only Acts and Is, in existing beings or Men' [The Marriage of Heaven and Hell (1793)]. Correspondingly, Samuel Taylor Coleridge (1772-1834) 
conceptualizes the 'Soul of each' as 'God of all' [The Eoliean Harp (1795-1817)]. Johann Wolfgang von Goethe (1749-1832) thinks if God did not inspire the bird with the powerful instinct towards its young in feeding it, and if the same did not pervade every living thing in nature, the world would not be able to exist! But divine power is spread everywhere and eternal love is active everywhere [Conversations with Eckermann, 29 May 1831]. Oscar Wilde (18541900 ) says that we are made one with what we touch and see and we are resolved into the supreme air, with our heart's blood each crimson sun is fair, with our young lives each springimpassioned tree flames into green, -all life is one [Panthea]. Walt Whitman (1819-1892) hears and beholds God in every object [I hear and behold God in every object] (Adapted from Romantics: Nature-Worship and Pantheism by Harrison).

So, from the above texts and references we have got the ideas of pantheism as: God pervades every living thing; Natural objects are the Vision of God, and: Soul of every natural object is God of all. But the holy Quran declares: "Whatever is in the heavens and on earth, declares the Praises and Glory of Allah: for He is the Exalted in Might, the Wise" (61:1). From the verse it can be understood that natural elements declare the praises and Glory of God, they themselves do not represent God. Though Goethe's remark that God pervades every living thing in nature is objectionable from Islamic perspective, his very statement: "divine power is spread everywhere and eternal love is active everywhere" supports the above verse.

\title{
Pantheism in Wordsworth
}

The greatest contribution of Wordsworth to the poetry on nature is his use of unqualified Pantheism-'making nature itself divine'. "If to follow the traditional poetic habit of imaginatively giving life to all experience, and of imaginatively unifying all experience, is to be a pantheist, then Wordsworth was a pantheist" (Durrant 1979: 16). He believes God shines through all the objects of nature, investing them with a celestial light. He finds Him in the shining of the stars; he marks Him in the flowering of the fields. This immanence of God in nature gives him mystic visions. Nature is no longer a mere vegetation; subject to the law of growth and decay; not a collection of objects to be described but a manifestation of God. Wordsworth came to believe that beneath the matter of universe there was a soul, a living principle, acting, even thinking. It may be living, at least, speaking to him, communicating itself to him:

\author{
And I have felt \\ a presence that disturbs me with the joy \\ Of elevated thoughts; a sense sublime \\ Of something far more deeply interfused, \\ Whose dwelling is the light of setting suns, \\ And the round ocean and the living air, \\ And the blue sky, and in the mind of man: \\ A motion and a spirit, that impels \\ All thinking things, all objects of all thought, \\ And rolls through all things [Tintern Abbey, 95-102 (1798)].
}

The chief faith of Wordsworth, namely, his pantheism, is lyrically expressed in this poem. Here the poet 'most directly expresses the sense of a unifying spirit within all things' (Durrant 1979: 6). Thus Wordsworth identified 'God and Nature as one' (Coles 1991: 45). In The White Doe the idea is called 'natural lord': Gone are they, bravely, though misled, /With a dear Father at their head!/ The sons obey a natural lord (Danby 1979: 133). In lines 6-8 of "It is a beauteous evening", the speaker begins to address someone who turns out to be a young girl. He tells her to listen that 'the mighty Being is awake' and making a 'sound like thunder' that lasts forever. The speaker then tells the child (actually his daughter, Caroline) who is walking beside 
him that even though she isn't affected by the solemn ideas he has when he comes face to face with nature, she is not any less divine. In fact, she 'liest in Abraham's bosom all year', because God is with her even when she is not aware of Him: Thou liest in Abraham's bosom all the year;/ And worship'st at the Temple's inner shrine/ God being with thee when we know it not (Lines 9-14). Wordsworth foreshadows Nietzsche's doctrine of the will to power when he states that 'there is an active principle alive in all things' which seeks to move beyond itself: All beings have their properties which spread/ Beyond themselves, a power by which they make/ Some other being conscious of their life (O' Dwyer 2008). In the woodcock episode of Book I, for example, the boy has stolen someone else's bird. In the context of solitude, darkness, and guilt, the effect is chastening, for the boy senses that, in breaching his own ethics, he has also offended that life beyond himself: "and when the deed was done/I heard among the solitary hills/Low breathings coming after me, and sounds/ Of undistinguishable motion" (Prelude 321-24).

So, from the above discussion we find that Wordsworth thinks of the unifying force of Nature as God and God in nature appears in different names like spirit, life beyond physical world, a mighty/powerful Being, a living principle, an undistinguishable motion, and natural lord, etc.

\section{Pantheism in Christianity}

Naturally many may believe that the very idea of Wordsworth's Pantheism is the idea of Christianity. But Christian idea of Pantheism that Wordsworth holds derives from two gospel roots. The first one is St Paul, as he states: "For in him we live, and move, and have our being". Though it is believed to be his statement, it is rather a quotation from a Greek poet, Aratus, probably influenced by the Stoic Cleanthes, who was a pantheist. In his own words Paul implies something similar when he says of Christ-God: "For by him all things were created... He is before all things and in him all things hold together" [Colossians 1: 16-17]. The second root of Christian pantheism lies in the idea of the Holy Spirit. The Gospel of John and the Epistle of John both extend the idea of the Holy Spirit, so that it will fill all Christian believers and guide them. Later theology identified the Holy Spirit as an integral part of the Trinity, and therefore part of God. If the Holy Spirit entered each believer, this meant that God entered. Like Paul's position this too was a form of selective panentheism (Islamic Pantheism).

On the contrary, the following Biblical references are different from Wordsworth's above discussed pantheistic idea: "I am God, and there is none else; I am God, and there is none like me" (Isaiah 46:9), and: "Thou shalt not make unto thee any graven image, or any likeness of anything that is in heaven above or that is in the earth beneath, or that is in the water under the earth. Thou shalt not bow down thyself to them, nor serve them: for I the Lord thy God am a jealous God" (Exodus 20:3-5) (qtd. in Naik 2011a). The following statement gives a clearer idea of Christianity regarding pantheism: "In contrast to Eastern religions, where God is seen as everything (pantheism), or in everything (panentheism), the biblical teaching is that there is an eternal, personal and infinite God who is not to be confused with his creation" (Muehlenberg 2010).

\section{Some Muslim Mystics on Pantheistic Concepts}

In discussing on pantheism, discussion of sufism appears naturally, because they are similar in many respects. Hence, the term 'Sufism' is misleading, as it is said that: "man safa min kullil ma'sia fahua sufi"-whoever is free from all sorts sins is sufi. So instead of sufism, mysticism is appropriate. But here we have used the term sufism because of its popularity. Here discussion on sufitic concepts is important, because the researchers of other religions and some Muslim pundits hold the views of sufism as the ideas of Islam, some even term the views as 'Islamic pantheism'. 
For example, Wiseman (1990: 230-1) holding the view of Hallaj as the idea of Islam, observes that in Islam claiming God and men as the same entity has been more frequent, especially among the sufis. As a proof he has mentioned the following extracts from Hallaj's poetry:

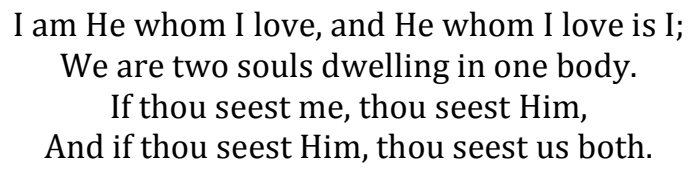

Likewise, some sufis and Muslim mystics have merged the concept of oneness/monotheism (tawhid) with the concept of pantheism. According to them, the existence of all created things is God's existence. Among them, Ibn al-'Arabi is of great fame. He believes, 'Everything that exists is a part of and a manifestation of the Oneness of God. Humans are part of God. The idea of a separate self is the result of ignorance' (Islamic Pantheism).

Actually the idea of Ibn al-'Arabi is not pantheism, but panentheism. Panentheists believe that God is present in the sensible universe, but also extends beyond it. One source of Ibn al-'Arabi's panentheism is mysticism, which seeks to efface the self in mystical union with God. Another source is some Quranic verses like: "Wheresoever you turn, there is the face of God". (2:115) which can be interpreted as 'you will face Allah whichever direction you turn your face' (Ali 1992: 49), for: "Allah hath power over all things" (2:109). Moreover, Allah knows well that many may misinterpret it, so He says in the next verse: "they say-Allah hath begotten a son--glory be to Him - Nay, to Him belongs all that is in the heavens and on earth; everything renders worship to Him" (2:116). Ibn al-'Arabi believed that God has a transcendental as well as an immanent aspect. He is manifested in, but also extends beyond the material universe. He has a hidden, veiled side. The texts that contain the ideas of Ibn al-'Arabi are from The Bezels of Wisdom [BW], translated by R.W.J Austin, Paulist Press, New York 1980, and The Treatise on Being, [TB] translated by T. H. Weir, Beshara Publications, London 1976. But the true authorship of the Treatise on Being is not known. It was probably written by a disciple of Ibn al-'Arabi. The ideas are as follows:

\section{a. God is all things;}

i. The Cosmos is His form. The forms of the Cosmos are the manifest Reality, He being the manifest. He is also their inner essence, being also the unmanifest. He is the first, since He was when they were not, and also the Last, since in their manifestation $\mathrm{He}$ is the Essence. [BW].

ii. God is essentially all things. He permeates through all beings created and originated. [BW].

iii. He is Being itself, the Essence of Being, He is the Preserver of all. In preserving all things, He is preserving His form, lest anything should assume a form other than His Form, which is not possible. [BW].

iv. The existence of all created things is His existence. Thou dost not see, in this world or the next, anything beside God. [TB]

b. Identity of self and God;

i. Thou art not thou: thou art He. Thou never wast nor wilt be, Thou art neither ceasing to be nor still existing. Thou art He. [TB]

ii. He who knows himself understands that his existence is not his own existence, but his existence is the existence of God. [TB]. (Adapted from A History of Pantheism and Scientific Pantheism by Harrison). 
Here idea like 'God is essentially all things', is similar to Wordsworth's' 'Whose dwelling is the light of setting suns, the round ocean, the living air and the blue sky', and pantheistic. So the idea is contrary to Islamic monotheism, because Allah says: 'there is nothing like Him' (AlQuran 42:11). Some Sufis of India also inherited pantheistic conception of divine unity. In course of time, this pantheistic conception was fully developed in the hands of the Indian Sufis and before the completion of two or three centuries, it became so much loose that it went far beyond the ordinary limit of toleration, necessitating a regular reformatory movement. It is interesting to note here that the unity of Godhead, as well as the pantheistic view of this unity was old things in Indian philosophy which also formed a background of Indian Sufism (Hoque 1995: 63). This indicates that the background of Indian Sufism is not based on Islamic tenets; rather it is based on old Indian philosophy. Moreover, the idea of Divine unity of Sufism leads to the theory of 'All is He', i.e. that manifest in the universe is God:

The beginning and the end, the manifest and the hidden-all is He, Alone He was, alone He is, and alone He will be [Chisty] (qtd. in Hoque 1995: 67).

Some mystics believe that all that exist are the essence of God:

His attributes, name and sign-all these Which exist are the very essence and Allah is a component whole [Abdul Karim Jily] (qtd. in Hoque 1995: 69).

Whatever thou seest is, in reality, He,-Candle, flower, moth, nightingale-all is from Him

[Bu'aliQalander] (qtd. in Hoque 1995: 68).

They also think that there is no distinction between phenomena and God. Again they hold the idea that good or bad that comes to sight is He:

\author{
Where is wine (i.e. divine love) and the cup and who is my cup-bearer (i.e. God)? \\ Be silent, O Muinuddin do not talk, -- all is He \\ [Chisty] (qtd. in Hoque 1995: 70). \\ Whatever comes to sight good or bad, \\ Is the essence of the Reality, $O$ the unaware! \\ [Bu'aly Qalander] (qtd. in Hoque 1995: 70).
}

So, like Wordsworth and other pantheists, above mentioned Muslim Sufis and mystics also believe that all that exist are the essence of God. But Muslim mystics, unlike Wordsworth, believe in limitlessness (transcendence) of God. Because they think that existence of phenomena is dependent on the existence of God; but God's existence is not dependent on the phenomena:

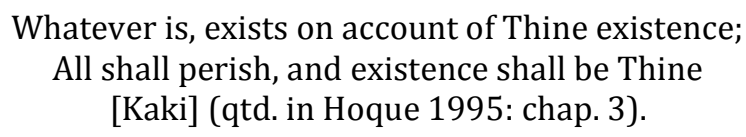

Generally, Sufis and Sufi scholars claim that Sufitic ideas are not pantheistic. For example, Golkhosravi (2001: 6) maintains: "neither Rumi nor Whitman is a pantheist; for they know human beings have a different nature and the world is not illusion. They transcend humankind to experience and taste the eternal nature of the human soul by being in love with the One". But many ideas by them are pantheistic (mentioned in the section Observation). Here Chittick's (2005: 31) observation is significant. He says that Islam's theological axiom, tawhid, declares that God is one, but it also asserts that the world is many. All of Islamic theological 
thinking addresses the issue of how to correlate multiplicity with unity. Those who look more at the divine side of things place greater stress on unity, and those who look more at the world emphasize multiplicity. As a general rule, rational thinking about God focuses on His separation from the world and the world's utter difference from His unique reality, and hence it highlights multiplicity and diversity. In contrast, imagistic or "imaginal" thinking about God tends to see the immanent unity established by God's presence in all things.

\section{Pantheism from the Islamic Perspective}

From above discussion, it is clear that the concept of pantheism is contrary to Islamic Monotheism (Tawhid). Although there are divergences within pantheism, the central ideas found in almost all versions are the Cosmos as an all-encompassing unity and the sacredness of Nature, representing God. This belief has hardly any place in Islam and is completely contrary to Monotheism.

We think that one should have respect for nature and God's creation, but one should not worship nature, as Wordsworth's pantheism indicates. So, Wordsworth's belief: “Whose (God's) $d$ welling is the light of setting suns,/And the round ocean and the living air,/ And the blue sky, and in the mind of man" can be modified as "Whose power and signs are the light of setting suns, And the round ocean and the living air, And the blue sky, and in the mind of man".

But Quranic literature is stronger in expression:

Among His Signs are the Night and the Day, and the Sun and the Moon. Do not prostrate to the sun and the moon, but prostrate to Allah, Who created them, if it is Him ye wish to serve (Al-Quran 41:37).

Islamic Monotheism, unlike pantheism, can be better understood in the following verses:

Thus did We show Abraham the kingdom of the heavens and the earth that he be one of those who have Faith and certainty. When the night covered him over with darkness he saw a star. He said: "This is my lord." But when it set, he said: "I like not that those who set." When he saw the moon rising up he said: "This is my lord." but when it set he said: "Unless my Lord guides me, I shall surely be among the erring people." When he saw the sun rising up he said: "This is my lord, This is greater." But when it set, he said: "0 my people! I am indeed free from all that you join as partners in worship with Allah. Verily, I have turned my face towards Him Who has created the heavens and the earth Hanifan (Islamic Monotheism, i.e. worshipping none but Allah Alone) and I am not of the $\mathrm{Al}$ Mushrikeen (those who worship others besides Allah) (Al-Quran 6:75).

Here it is clear that if God does not have separate entity, we need not turn our faces to Him. According to Islam, Allah is upheld as One, Unbegotten, Eternal, and Unequalled and beyond partnership of any kind. The following verses echo that:

Say: He is Allah, the One and Only; Allah, the Eternal, Absolute; He begetteth not, nor is He begotten; And there is none like unto Him (Al-Quran 112: 1-5).

So, Rabbani's (2011) observation regarding Islamic Monotheism that God is Immanent meaning 'everything is in God', but not confined to anything as no finite being can logically contain the Infinite Being, is contradicting to the third and fourth verses of the above mentioned surah. Again his idea that God's Transcendent not in the sense of an anthropomorphic Deity sitting on His throne in the upper regions, but in the sense of His Limitlessness encompassing the whole universe, the whole of space and beyond all space, is contrary to the ayah (verse) of the Quran: "al-Rahman 'ala al-'Arsyistawa" (20:5) which means that Allah firmly occupies His 
throne in His capacity as Rahman. Though the ayah is explicitly contrary to the ayah known as Ayatul Kursi: "His throne encompasses the entire universe", it indicates the sense of power, authority and knowledge of God (Ali 1992: 106).

Rabbani's concept encourages the idea of pantheism or panentheism which some Muslim mystics hold as we came to know earlier. The present study assumes Rabbani's (2011) conception about Allah's omnipresence, is true not in the sense that God is physically present everywhere, but in the sense of power, authority and knowledge. So: "His throne encompasses the entire universe" (2:255) means - in everything (both spiritual \& things of sense) is the working of Allah's power, and will, authority in the universe (Ali 1992: 106). And regarding the verse that indicates 'Allah's throne on which He is firmly established', Shafi (as cited Khan 1413 A.H) interprets that 'sitting on the throne' is true, but its nature is completely related to Allah. None of this world can realize it (p. 845). In this case, Ali (1992) interprets that Allah sits on the throne of Grace and Mercy (p. 765). So, the relationship of the universe with God is like that of an author with his book, which owes its existence to the author. Again according to the big bang theory, right after the big bang, the physical space, matter and time were created. The creator has to be free of matter, time and space to be able to create the universe. So, we assume God and His creation have separate entities. God is All-Embracing and All Powerful. If we think everything in the universe is God's Being and nothing can be separated from God, it indicates everything is a part of God and God will be confined to some limited things which God Himself created. Whereas what God has created is finite, God is Infinite. In this case, Rabbani's (2011) opinion is relevant:

In Islam, although the universe is not separate from God's Being, the concept of the Universe as a part of God's Being is both irrational and untenable in that it presupposes divisibility when God is Indivisible. Allah says: "There is nothing like Him, and He is the All-Hearer, the All-Seer" (Al-Quran, 42:11)

Naik (2011: 4) says in this regard: "Islam exhorts man to consider himself and his surroundings as examples of divine creation rather than as divinity itself".

\section{Observations}

This study observes that Wordsworth as well as other western pantheists and Muslim mystics, perhaps, do not lack belief in God, but it is their misunderstanding and wrong way of presentation which made them develop such concepts and ideas that went contrary to the basic spirit of tauhid (Islamic Monotheism). If we look at the attributes of Allah, many of them will reject these ideas. For example, Allah says: "Allah is the Eternally Besought" (Al-Quran 112:2). But no creation is eternally besought. So the ideas they presented can be analysed on the basis of Islam with some modifications in the following ways:

\begin{tabular}{|c|c|}
\hline $\begin{array}{l}\text { Ideas of pantheism and } \\
\text { Sufism }\end{array}$ & Ideas modified on the basis of Quranic reference \\
\hline $\begin{array}{l}\text { Pantheism: All is God/ All is } \\
\text { He/ Everything is God. }\end{array}$ & $\begin{array}{l}\text { All is God's/ All is His or all belongs to Him/ Everything is God's or } \\
\text { everything is the sign of God's essence (zat). }\end{array}$ \\
\hline $\begin{array}{l}\text { Sufism: All is in God/ All is in } \\
\text { Him/ Everything is in God. }\end{array}$ & $\begin{array}{l}\text { Ref.: } \\
\text { a. To Allah belong the East and the West: whithersoever ye } \\
\text { turn, there is Allah's countenance. For Allah is All- } \\
\text { Embracing, All-Knowing (Al-Quran 2:115). } \\
\text { b. And there is none like unto Him (Al-Quran 112:4). } \\
\text { c. They say: "Allah hath begotten a son": Glory be to Him- }\end{array}$ \\
\hline
\end{tabular}




\begin{tabular}{|c|c|}
\hline & $\begin{array}{l}\text { nay, to Him belongs all that is in the heavens and on earth: } \\
\text { everything renders worship to Him (Al-Quran 2:116). } \\
\text { d. His are all things in the heavens and on earth-(Al-Quran } \\
2: 255 \text { ) }\end{array}$ \\
\hline $\begin{array}{l}\text { Pantheism: God is everything } \\
\text { Sufism: God is everything and } \\
\text { beyond }\end{array}$ & $\begin{array}{l}\text { God's power is in everything, i.e. Allah's power is working in } \\
\text { everything. } \\
\text { Ref.: } \\
\quad \text { a. Allah hath power over all things (Al-Quran, 2:109). }\end{array}$ \\
\hline $\begin{array}{l}\text { Pantheism \& Sufism: } \\
\text { God/Allah is everywhere }\end{array}$ & $\begin{array}{l}\text { God/Allah is on His 'Arsy (throne), but He has the power to look } \\
\text { over everything. } \\
\text { Ref.: } \\
\text { a. Al-Rahman 'ala al-Arshistawa (20:5) which means that } \\
\text { Allah firmly occupies His throne in His capacity as } \\
\text { Rahman. } \\
\text { b. Moreover, in many Quranic verses the term 'Nazil' } \\
\text { (revelation) has been used for bestowing anything down } \\
\text { to His creation, especially to Man. } \\
\text { c. Again, the attribute 'Al-Basir' meaning the All-Seer is } \\
\text { contrary to the idea that God is everywhere. }\end{array}$ \\
\hline
\end{tabular}

Holding the view 'everything is God and vice-versa, thinking them as parts of God' is obviously contradictory to the spirit of Tauhid (theism) as well as Islamic tenets, as it is the demand of Tawheed that creation cannot represent the Creator but proclaims the existence of the Creator and unlike the Creator, creation is subject to decay and death. In the Holy Qur'an Allah declares: "All that is on earth will perish: But will abide (forever) the Face of Thy Lord-full of Majesty, Bounty and Honour" (Al-Quran 55:26-27). So, no Muslim, like Wordsworth and other pantheists and mystics, can hold the belief that everything which exists is literally a part of God, and there is no demarcation between creation and Creator. But we should say that they are the signs, on observation of which we can understand God and pay Him homage. Allah, the Exalted, says:

Verily! In the creation of the heavens and the earth, and in the alternation of night and day, there are indeed signs for men of understanding. Those who remember Allah (always, and in prayers) standing, sitting, and lying down on their sides, and think deeply about the creation of the heavens and the earth (Al-Quran 3:190-191).

\section{References}

'Ali, A. Y. 1992. The Meaning of the Holy Quran. Maryland: Amana Corporation.

Al-Attas, S. M. N. 1995. Prolegomena to the Metaphysics of Islam. Kuala Lumpur: International Institute of Islamic Thought and Civilization.

Chittick, W. C. 2005. The Sufi tradition: Sufism (A beginner's guide). Oxford: OneWorld.

Coles Editorial Board. 1991. Wordsworth's poetry notes. New Delhi: Rama Brothers.

Danby, J. F. 1971. The simple Wordsworth studies in the poems 1797-1808. London: Routledge \& Kegan Paul.

Durrant, G. 1979. William Wordsworth. Cambridge: Cambridge University Press.

Eagle, D. 1970. The Oxford concise dictionary of English Literature. Oxford: Oxford University Press.

Golkhosravi, M. 2001. 'Panentheistic' view of Divine Love in man and nature: A comparative study in Whitman's Leaves of Grass and Maulana Jalal al-Din Rumi's Mathnavi. University 
of Barcelona: Edicions i Publicacions de la Universitat de Barcelona. http://www.publicacions.ub.es/revistes/bells13/PDF/articles. [20/08/2013].

Hoque, M. E. 1995. Main principles of Sufism as expounded by the Indians (including Bengali) Sufis. In M. Musa (Ed). Muhammad Enamul Hoque Rachanabali (Essays of Muhammad Enamul Hoque), pp. 63-70. Vol. 4. Dhaka: Bangla Academy.

Harrison, P. A. 2013a. History of pantheism and sientific pantheism. World Pantheism. http://www.pantheism.net/paul/history.htm. [3/05/2013].

Harrison, P. 2013b. Romantics: nature-worship and pantheism. World Pantheism. http://www.pantheism.net/paul/poets.htm. [3/05/2013].

Islamic Pantheism. Wikipedia. http://en.wikipedia.org/wiki/Islamic_pantheism. [3/05/2013].

Mander, W. 2012. Pantheism. Stanford Encyclopedia of Philosophy. In Edward N. Zalta (ed.). Stanford: Stanford University.

Muhlenberg, B. 2010. Pantheism and Biblical Christianity. Culture Watch. http://www.bil Imuehlenberg.com/2010/01/09/pantheism-and-biblical-Christianity. [3/05/2013].

Naik, Z. Concept of God in Christianity. 2011a. Concept of God in major religions. http:// www. Irf.net/index. [13/12/2011].

Naik, Z. Concept of God in Hinduism. 2011b. Concept of God in major religions. http://www. Irf.net/index. [13/12/2011].

O' Dwyer, K. 2008. The Question of love's possibility explored through the poetry of William Wordsworth. Cosmos and History. The Journal of Natural and Social Philosophy 4(1-2).

Pantheism. 2005. Wordsworth and pantheism. http://literarydiscussions.myfree forum.org/sutra308.php. [3/05/2013].

Rabbani, H. W. B. 2011. The Sufi conception of God. Self-Knowledge. http://cyclewalabanda.blogspot.com/p/sufi-conception-of-god.html. [10/06/2011].

Ramli, A. M. 2011. Straying imagination, righteous intuition: The English romantic movement and the Islamic Philosophy of Muhammad Iqbal (1873-1938). Paper presented at International Conference on Humanities 2011, (INCOH 2011). USM, Parkroyal Hotel, 1316 June 2011.

Shafi, M. M. 1413 A.H. Holy Qur'anul Karim (Origin: Tafsir Ma'riful Qura'n). M. M. Khan (Trans. \& Ed). under the patronization of the Ministry of Hajj \& Auqaaf, Madina: The Khademu Haramain Sharifain Badshah Fahd Qura'n Printing Project.

Wordsworth, W. n.d. Wordsworth's poetical works summary and analysis. http://www.gradesaver.com/wordsworths-poetical-works/study-guide/section4 $[3 / 05 / 2013]$.

Wiseman, J. A., O.S.B. 1990. To be God with God: The autotheistic syings of the mystics. Theological Studies. The Catholic University of America. 